\title{
La literatura como Historia alternativa de las mujeres rurales andaluzas: el caso de Hijas de un sueño*
}

\section{Resumen}

En noviembre de 2017, vio la luz Hijas de un sueño, mi primera colección de relatos donde abro las puertas de Candiles, un pueblo imaginario ubicado en algún lugar de Andalucía oriental, cuyas protagonistas son mujeres rurales que buscan salir de su anonimato y dejar huella en una Historia alternativa. El reto de este estudio es posicionarme como académico y crítico literario feminista, para demostrar que mi localización en el Sur peninsular no está exenta de carga ideológica, tal y como se refleja en mi creación literaria. Mientras que defiendo cierta especificidad sociocultural para Candiles, la transcendencia universal de sus límites geográficos aboga finalmente por un antiesencialismo regionalista, étnico, sexual y de clase, para dibujar personajes complejos y empoderados. Partiendo de conceptos como «hegemonía», «sentido común» o «ideología», coincido con Ania Loomba en la posibilidad de explorar un espacio de subversión dentro de la ideología dominante y esgrimo su redefinición del colonialismo ligada a nacionalismos trasnochados, y existente incluso entre los países occidentales o dentro de una misma nación. Entiendo mi escritura, pues, como un reflejo de la subalternidad del Sur español. Mi caso de estudio será el relato «Doce mariposas», donde invento una leyenda para Candiles, vagamente ubicada en el siglo XIX. La subalternidad andaluza por cuestiones geográficas e históricas, el esencialismo biológico de la «literatura femenina» y la violencia de género ligada al uso estratégico de la leyenda, el cuento de hadas y el palimpsesto, conducirán a la propuesta de una Historia alternativa para las mujeres andaluzas más allá de la falsa objetividad histórica del patriarcado.

Palabras clave: Historia; literatura; mujeres rurales; Andalucía; violencia de género; folklore; feminismo; cuento.

Citar: Rodríguez Salas, G. (julio-diciembre 2018). La literatura como Historia alternativa de las mujeres rurales andaluzas: el caso de Hijas de un sueño. La Palabra (33), 99-127. doi: https://doi.org/10.19053/01218530.n33.2018.8142

\section{Gerardo Rodríguez Salas}

Profesor titular de Literatura en lengua inglesa, en la Universidad de Granada (España). Cuenta con un Máster en Estudios de Género, en la Universidad de Oxford (Reino Unido) y un doctorado parcialmente escrito en Nueva Zelanda, bajo la supervisión del poeta laureado Vincent O'Sullivan. Actualmente, sus intereses investigadores giran en torno a teorías comunitarias y de género aplicadas a la literatura. Entre sus libros, destacan: Hijas de la Diosa Blanca: ginocrítica y feminismo (2007), Katherine Mansfield: el posmodernismo incipiente de una modernista renegada (2009), The Aesthetic Construction of the Female Grotesque in Katherine Mansfield and Virginia Woolf (2011), Community in Twentieth Century Fiction (2013) y New Perspectives on Community and the Modernist Subject (2018). En noviembre de 2017, se estrenó como escritor de ficción con la colección de relatos Hijas de un sueño.

gerardor@ugr.es

*Artículo de investigación. 


\section{la palabra}

Literature as History of Rural Andalusian Women: The Case of Hijas de un sueño [Daughters of a Dream]

\section{Abstract}

My first short story collection, Hijas de un sueño [Daughters of the Dream] was published in November 2017. In this book I open the doors of Candiles, an imaginary rural town located somewhere in Eastern Andalusia. Its protagonists are rural women who seek to step out of their anonymity and leave their imprint on an alternative History. The challenge of this study is to position myself as a feminist literary critic, so as to prove that my location in the South of Spain is not free of ideology, as reflected in my creative writing. While I demand a socio-cultural specificity for Candiles, the universal transcendence of its geographical limits ultimately takes a stance for a regionalist, ethnic, sexual and class anti-essentialism that allows me to create complex and empowered characters. Taking concepts such as 'hegemony,' 'common sense,' or 'ideology' as a starting point, I agree with Ania Loomba that there is a possibility to explore a subversive space within the dominant ideology, and I adhere to her redefinition of colonialism, linked to outdated nationalisms, existing even among Western countries or inside the regions of the same country. I thus understand my writing as a reflection of Southern subalternity. My case study will be the short story 'Twelve butterflies' ('Doce mariposas'), where I make up a legend for Candiles, vaguely located in the 19th century. The geographical and historical subalternity of Andalusia, biological essentialism in 'feminine literature', and gender violence as linked to the strategic use of legends, fairy tales and palimpsest, will lead to the proposal of an alternative History for Andalusian women beyond the false historical objectivity of patriarchy.

Keywords: history; literature; rural women; Andalusia; gender violence; folklore; feminism; short story.

\section{La littérature pour retracer l'histoire des femmes rurales en Andalousie: l'exemple de Hijas de un sueño [Filles d'un rêve]}

\section{Résumé}

En novembre 2017, Hijas de un sueño, mon premier recueil de nouvelles a vu le jour. J'y ouvre les portes de Candiles, un village imaginaire situé dans la région de Grenade. Les protagonistes sont des femmes rurales, qui cherchent à sortir de l'anonymat et qui veulent laisser leur empreinte dans l'Histoire "alternative". Le défi de cet article est de me positionner en tant que chercheur et critique littéraire 
féministe pour démontrer que le fait de venir du Sud de la péninsule ibérique implique une charge idéologique qui se reflète dans ma création littéraire. Alors que je défends une certaine spécificité socio-culturelle pour Candiles, la transcendance universelle de ses limites géographiques plaide en faveur d'un anti-essentialisme régionaliste, ethnique, sexuel et classiste perceptible au travers de personnages complexes et émancipés. En partant de concepts tels que "l'hégémonie", le "bon sens" ou "l'idéologie", je rejoins Ania Loomba qui considère la possibilité d'explorer un espace de subversion au sein d'une idéologie dominante. Dans ce sens, je reprends sa redéfinition du colonialisme liée aux nationalismes dépassés mais encore vifs dans les pays occidentaux ou dans une même nation. J'envisage ainsi mon écriture comme le reflet de la subordination du Sud espagnol, qui cherche à rendre visible des voix marginalisées. Mon étude se centrera sur la nouvelle "Doce mariposas" [Douze papillons] dans laquelle j'invente une légende pour Candiles, dont je situe l'origine à peu près au XIXème siècle. La subordination andalouse pour des raisons historiques et géographiques, l'essentialisme biologique de la "littérature féminine" et la violence de genre liée à une utilisation stratégique de la légende, le conte de fée ainsi que le palimpseste, génèrent une histoire alternative pour les femmes andalouses au-delà de la fausse réalité objective du patriarcat.

Mots-clés: Histoire; Littérature; femmes rurales; Andalousie; violence de genre; folklore; féminisme; conte.

La subalternidad del Sur español: ideología, Historia, literatura y costumbrismo

Gramsci distingue entre «filosofía» y «sentido común» para explicar el impacto de la ideología, y define lo último como aquello que es «verdadero», común a todo el mundo o «normativo», ${ }^{1}$ lo cual conduce a entender las ideologías como estructuradoras de masas humanas y creadoras del terreno sobre el que nos movemos, adquirimos conciencia de nuestra posición y combatimos (1971, pp. 324, 377). La hegemonía, por tanto, se forma combinando coerción y consentimiento, no solo por adoctrinamiento directo, sino también moldeando el sentido común (p. 387). Louis
Althusser completa esta visión gramsciana, aclarando que en las sociedades capitalistas modernas "la fuerza se consigue a través de los aparatos ideológicos represivos" (e.g. ejército, policía), y el consentimiento a través de los «aparatos ideológicos estatales» (e.g. escuelas, iglesia, familia, medios, sistemas políticos), mediante los cuales el sistema dominante crea sujetos que, por medio de lo que él denomina «interpelación», asumen identidades ideológicamente manipuladas que aceptan los valores del sistema (1971, pp. 218-219).

Sin embargo, según esta visión determinista de Althusser, puesto que los sujetos se forman dentro de las ideologías, no hay espacio para una batalla ideológica e ideas de oposición. Ania Loomba concluye, al respecto, que estas ideas de Althusser son demasiado funcionalistas, puesto que enfatizan la función, pero no la complejidad tanto de las instituciones como de los sujetos humanos (1998, p. 33). Michel Foucault lleva la idea de la dependencia del sujeto al extremo y, en efecto, al reconocer la muerte del autor/a, concluye que el poder no emana de una estructura central o jerárquica, sino que fluye en la sociedad como una especie de acción capilar: el poder está en todos lados no porque se agarre a todo, sino porque procede de todas partes (1990, p. 93).

Stuart Hall aclara que el sentido común es una amalgama de ideas en las que se forma la conciencia práctica de las masas de gente (1996, p. 431). 
El presente estudio parte de mi posicionamiento ideológico como escritor y como crítico literario, para repensar, desde mi propio conocimiento situado (Haraway, 1988), mi entendimiento del Sur peninsular español como lugar de subalternidades. Hablando de Federico García Lorca, escritor central granadino que resuena en $\mathrm{mi}$ obra, José Ortega opina que «es esencial identificar la ideología del autor [...] ya que esta ideología, como sistema articulado del mundo, incide en su obra» (1981, p. 9). Al respecto, Ortega aclara que «[1]a subjetividad del autor real importa no como algo abstracto o independiente de la vida social, sino como producto histórico que responde a valores ideológicos concretos» (pp. 9-10).

Mi construcción ideológica como crítico y escritor, se proyecta en la ubicación geográfica andaluza y el pueblo imaginario que habitan mis personajes en Hijas de un sueño, un claro foco de subalternidad sureña. El punto de partida en mi obra es la teorización del colonialismo que ofrece Loomba, quien habla de la dificultad de teorizar este concepto y del peligro reduccionista que supone. En su lugar, presupone un conjunto de prácticas heterogéneas (1998, p. xii) que bien podrían hacer extensiva dicha realidad a las distintas naciones occidentales o incluso a distintas zonas dentro de un mismo país, como es el caso de Andalucía. El suroeste de España o la Andalucía oriental, donde se ubica el pueblo ficticio de Candiles, se alza como un doble locus subalterno: por un lado, con respecto a la nación española (Ruiz Muñoz, 2008, p 126; Trenzado Romero, 2000, p. 197); por otro, con respecto a la capital hispalense y su «centralismo andalucista», que conduce a una identificación de lo andaluz con lo sevillano (Galán Fernández, 2016, p. 3; Guarinos, 1999, p. 114).

El esencialismo en el que ha caído durante siglos la identidad andaluza, es indiscutible. Como afirma Nerea Cristina Galán Fernández, refiriéndose a la Andalucía sublimada celebrada por Ortega y Gasset en su Teoría de Andalucia, «la identidad de Andalucía se ha convertido en materia estética mil veces falseada» (2016, p. 1). Al hablar de literatura regional, Galán percibe ciertos rasgos comunes, tales como la tematización del contexto andaluz, el compromiso del realismo social o el populismo que, «instintivamente», se encuadran en una personalidad o estilo andaluz que presume «cierto carácter etno-esencialista» (pp. 1-2). La Andalucía mítica y literaturizada de la que habla Galán, se fraguó durante el siglo XIX, cuando los militares británicos participantes en la Peninsula War (1808-14) informaron del pintoresquismo del sur a su regreso (p. 3) y, como aclara Carmen de Urioste, Andalucía se convirtió en «exotismo literario» mediante la «fijación de los arquetipos míticos» (1997, p. 101). A partir de ese momento la Historia de Andalucía, se desdibuja pues, como aclara Galán, el mito «des-historiza» y «la historia regional andaluza - su realidad política, social y económica - es eclipsada por la acumulación de tópicos que esta materia instala en la base de la comprensión de la identidad surespañola» $(2016$, p. 3$) .^{2}$ Este peligroso acercamiento de historia y mito, será revisado como un espacio fronterizo que permite recrear una Historia alternativa para las mujeres andaluzas en el relato que analizaré más adelante. ${ }^{3}$

Sin duda, la figura de Blas Infante es ineludible para explicar el idealismo de Andalucía que pervive durante el siglo XX. Infante trata de encontrar la «esencia» andaluza en el ruralismo, siguiendo la estela del

2 Luis Cernuda ilustra esta imagen mítica: «no la busquéis en parte alguna porque no estará allí. Andalucía es un sueño que varios andaluces llevamos dentro. Nada sabemos de la otra, la baja Andalucía, ni de sus modas chillonas y vanidad» (1975, p. 1128).

3 Montenegro de la Hoz (2014), Vanegas Vásquez (2014), Sierra Díaz (2016) y Maglia (2017) proponen estudios similares que revisan valores históricos míticos en la literatura en su relación con regiones específicas de Latinoamérica y el Caribe. 
Paraíso Perdido de sus antecesores: «El pueblo andaluz, puro o auténtico, es el distribuido por las zonas rurales: campesinos con o sin campos, en los cuales, relativamente, no existe la mezcla de sangre andaluza con sangre extraña que vino a operarse en los grandes centros urbanos» (1915, pp. 316-17). Infante idealiza el genio andaluz y describe la unión sagrada del hombre y la tierra, esas «nupcias benditas» en las que deposita «las esencias que harán revivir poderosas energías agonizantes del genio andaluz» (1982, p. 207). Galán concluye que en Infante encontramos no a un revolucionario, sino a un padre edénico y romántico que potencia un mito en lugar de una historia:

[...] sus disertaciones sobre el ser de Andalucía parten de la falacia edénica, coadyuvando a la perpetuación de la matriz romántica operativa en la producción del discurso de identidad regional decimonónico. Los intentos de dignificación nacionalista de Infante, bajo la forma de lo sublime, conformarán una diatriba mística en que el fondo social adquiere también tintes estéticos transcendentes, en lugar de proyección revolucionaria. Lo que originalmente era un discurso inserto en la lógica de una época y unas condiciones históricas determinadas, termina por echar raíces en el suelo andaluz y se que- da, no solo como Historia, sino como manera de hacer la Historia. (2016, p. 5).

Otras críticas y críticos reconocen el patriotismo y carácter esencialista de Infante en su Ideal andaluz (de Urioste, 1997, p. 105). Isidoro Moreno concluye que Infante consideraba lo andaluz como «una esencia permanente, mantenida a través de los siglos e incluso milenios, pujante y explícita o debilitada y oculta, según las épocas, pero siempre pujante» (1981, p. 258). Infante defendía el cultivo de una nueva literatura regionalista:

Es preciso que acabe la anodina labor de una literatura estéril, que arrastra el último grado de la decadencia, y que se ofrece con prodigalidad en versos, crónicas, narraciones, trabajos de sociología y filosóficos [...] sin otra metafisica que la metafísica de una monótona canción de grillos, forjada por raquíticas imaginaciones, que imagina, para sentir lo que no se siente, o por inteligencias incapaces de albergar un pensamiento con alas; esto es, sin alientos para elevarse sobre la triste actualidad y remontar el vuelo, huyendo de las sombras de lo pasado en busca del faro de lo porvenir. (1982, pp. 294-295).

Sin embargo, recientemente se habla de "antinacionalismo» en Infante. En la pri- mera edición crítica de Ideal Andaluz coincidiendo con su centenario, con prólogo de Juan Antonio Lacomba y estudio introductorio de Francisco Garrido Peña, este último concluye que Ideal Andaluz no es ni un texto literario, ni menos aún histórico, filosófico o científico, sino un ensayo político que persigue «la emergencia de "un pueblo" como sujeto político activo: el pueblo andaluz», si bien el objetivo final es un «universalismo ético»; esto es, Infante «rechaza el odio, el antagonismo, la venganza o el resentimiento como motores para la construcción emocional de la identidad andaluza» y defiende «la alegría y la cooperación entre los individuos y los pueblos» (1982, p. x). Garrido concluye, pues, que el nacionalismo andaluz de Blas Infante «no defendía ni mucho menos romper con el Estado, abogaba [...] por un Estado federal cooperativo, descentralizado, radicaldemocrático y sin el peso de la monarquía y la Iglesia Católica, en oposición al nacionalcatolicismo» (Andaluces Diario, 2016). Por todo esto, Garrido considera que Infante fue «un revolucionario moderado que quería cambiar la situación de penuria de la región sin crear conflictos insalvables» y considera que se le ha acusado de un falso esencialismo, debido al estilo confuso e incluso caótico de Ideal Andaluz, que «ha sido un grave obstáculo para su difusión, dando pie a 
que el texto haya sido objeto de múltiples interpretaciones esencialistas o teosóficas» (Centro Estudios Andaluces, 2015).

Una de las paradojas que se observa con relación al esencialismo andaluz, es su generalización para representar el esencialismo de España como nación: la voz subalterna que se hace mayoritaria. $M^{\mathrm{a}}$ Pilar de la Peña habla de Andalucía como una región que «en la centuria pasada se convierte en sinónimo de lo español, por lo que artistas de toda índole pondrán sus ojos en ella para recrear sus imágenes peculiares y valederas del orgullo nacional» (1994-5, p. 229). Galán explica que la afirmación de la identidad específica de Andalucía no convenía a la burguesía andaluza, plenamente integrada en el proyecto oligárquico centralista que sustentaba sus estructuras de poder, por lo que, «[p]ara absorber a Andalucía en su dominio ideológico e ideologizante, había que negarla. Siendo esto difícil por nuestro "sobrante de identidad", ¿qué mejor manera que extender la andalucidad sin fronteras, una andalucidad nacional para cortar de raíz cualquier posibilidad de resurgimiento regionalista?»(2016, p. 6).

José G. Ladrón de Guevara destaca el producto nacional grotesco como resultado de la ma- nipulación de una región como la andaluza «hasta desfigurarla y convertirla en un monstruoso tópico (la mala caricatura de ella misma) para exhibirla como bandera turística ante el mundo y los propios españoles» (1977, p. 92) y José Acosta Sánchez señalaba en plena transición que la especificidad de la alienación cultural de Andalucía consistía precisamente en la representación de España a través de lo andaluz, con la consecuente enajenación de la cultura andaluza mediante su españolización (1979, p. 66).

Ladrón de Guevara se remonta a la unificación territorial bajo el reinado de Los Reyes Católicos, para explicar el inicio de una «represión constante y sistemática» de la producción cultural andaluza (1977, p. 91), represión que llega a su culminación con el régimen del General Francisco Franco. Por tanto, para Ladrón de Guevara, la colonización cultural por parte de los centros de poder, ha sido permanente en la cultura andaluza durante cinco siglos.

En el campo de la literatura, de Urioste ofrece un interesante recorrido por la conformación de la literatura regional, que data en las tres primeras décadas del siglo XX y que destaca por presentarse como alternativa a la «unitaria voz nacional, pero no solamente con un carácter des- criptivo, sino con un significado político y testimonial» (1997, p. 97). De Urioste habla de «Andalucía de la denuncia» (p. 102), cuyas primeras manifestaciones surgen en 1909 y alcanzan su cumbre entre 1915-1936 con el paréntesis de la Dictadura de Primo de Rivera. El andalucismo político de dicha etapa está representado por Blas Infante y la Asamblea Regionalista de Ronda (1918), cuyo primer acuerdo, del que se desprenden los otros nueve, es el «Reconocimiento de Andalucía como país, nacionalidad y democracia autónoma que funda su origen político más cercano en la Constitución Cantonal de 1883» (cf. de Urioste, 1997, p. 102). Ángel Guerra (La España moderna, 1908) sienta las bases sobre las que se desarrollarán los estudios del regionalismo literario en el primer tercio del siglo XX, destacando así unas literaturas regionales «con carácter y alma propia» que buscan un «aislamiento necesario» para «evitar todo contagio» (p. 11).

Sin embargo, el carácter de «literatura de resistencia» que de Urioste otorga a estas «literaturas regionales periféricas» de las tres primeras décadas del siglo XX, se entiende más como «un periodo de fructífero regionalismo más cultural que político, un período de búsqueda de la propia identidad regional» 
(1997, p. 100). En efecto, para críticos como José M. Macarro, el regionalismo político no existió y solo la faceta cultural dio vida al movimiento ( $c f$. de Urioste, 1997, p. 103). Frente a los casos vasco y catalán (que se perciben como ejemplos de separatismo), el andalucismo se ve como «un regionalismo regeneracionista» (p. 104), no exento, sin embargo, de un cargado esencialismo, como se desprende de las descripciones de las revistas literarias del momento: Bética (Sevilla 191317), que habla de la «expresión de la verdadera vida andaluza», y Andalucía (Sevilla 1916-17), que habla de esta región como «la medicina que salvará al enfermo, porque es un ideal de vida el que defiende, la vida y la honra de todos los andaluces»» (cf. de Urioste, 1997, p. 107).

A finales de los 60-principios de $\operatorname{los} 70$, se produce una oleada de narrativa regional sin precedentes, los denominados narraluces, que coincide con el auge entre andaluces de novelistas y premios nacionales (del 68 al 73). Para ellos, y como dice Galán, el peso ideológico y sentimental del exilio económico andaluz, conduce a la re-idealización del mundo terrenal andaluz y a la renovación del topos del paraíso perdido (2016, p. 3). El concepto de folklore es central para entender la literatura andaluza. José Luis Agúndez explica que «cuando la búsqueda de lo popular es el objetivo en sí mismo para su análisis y estudio llegaríamos al estadio final del folclore» (2017, p. 637). Alejandro Guichot y Sierra ubica sus orígenes en El Folklore Español de Machado y Álvarez (3 noviembre 1881) y habla de «recolectores regionalistas» a partir de 1850, aquellos que separan lo popular de lo erudito (1922, p. 27). Tras ofrecer un interesante recorrido histórico del folklore, Agúndez esgrime un posicionamiento con tintes esencialistas cuando concluye que «es necesario averiguar, decantar lo verdaderamente popular. Lo que fue popular entonces y sigue siéndolo, para llegar a lo propiamente folclórico. Separar lo propio del pueblo de lo desechable que autores imitaban o, en el peor de los casos, elaboraron para él» (2017, p. 658).

Frente a la percepción negativa del folklorismo como asociado a tópicos (Ruiz Muñoz, 2008, p. 125), yo abogo en mi estudio por reinventar estereotipos sin renunciar a determinados rasgos costumbristas. Como dice Álvaro Salvador, debemos «mantener una conciencia puramente materialista de nuestra propia memoria histórica para producir conocimientos no ilusorios» (1980, p. 56). Antonio Chicharro aclara que «el hecho de que se hable de Andalucía, de que esta región pase a ser objeto de atención, no quiere decir que exista una literatura andaluza, sino en todo caso que existe una conciencia, tópica o no, generalmente deformada, que actúa como síntoma de que una realidad social se encuentra en movimiento, en transición» (1983, p. 48).

Para desmontar el montaje esencialista andaluz, es necesario desenmascarar la Historia como discurso irrefutable y objetivo, y como dice Loomba, aclarar que las crónicas históricas están sujetas a las mismas reglas, deslices y estrategias que otras narrativas, por lo que la línea que separa realidad y ficción se desdibuja o al menos se somete a un intenso escrutinio (1998, p. 40). Cristina Segura aclara que «las crónicas históricas tienen una fiabilidad cuestionable y siempre hay que utilizarlas intentando desprenderlas de la fuerte visión partidista de la que suelen adolecer» (2001, p. 14) y explica así el cuestionamiento de la Historia tradicional:

La Historia tradicional ha defendido que su construcción solo podía llevarse a cabo con la utilización de aquellos documentos escritos que habitualmente se han considerado como fuentes históricas: crónicas, protocolos notariales, documentación jurídica o económica, privilegios reales, cartularios de monasterios, etc. El "ver- 
dadero" pasado de la humanidad se encontraba en este tipo de documentos que recogían los hechos "tal como sucedieron". Estos escritos eran considerados las fuentes históricas idóneas, pues lo que se pretendía era una total objetividad, que sólo podía lograrse con la narración o descripción de los acontecimientos como se reflejaba en los escritos coetáneos a los sucesos. (p. 13).

En el caso de Andalucía, y como arguye Galán, «el referente sociohistórico se pierde por el camino, resultando un costumbrismo apolitizado que desarma cualquier intención de denuncia» (2016, p. 4). Puesto que la Historia construida para Andalucía, tal y como teorizan estas figuras críticas, es un constructo tan artificial como cualquier acto de literatura, ${ }^{4} \mathrm{mi}$ estrategia en el relato de «Doce mariposas» será demostrar el uso del cuento de hadas y del mito como géneros subalternos, para ofrecer un contra-discurso tachado de irreal y periférico, pero que proporciona el vehículo necesario para escuchar las voces subalternas de las mujeres rurales andaluzas.
Una Historia alternativa para las mujeres rurales andaluzas: cuestionando la violencia de género

Además de la subalternidad geográfica e histórica andaluza, al presente estudio se suma la doble alteridad de las mujeres rurales. Como aclara $\mathrm{M}^{\mathrm{a}}$ Dolores Ramos Palomo, «[t] radicionalmente la historiografía ha entendido la historia de la humanidad como sinónimo de determinadas formas de poder ligadas, por presencia o ausencia, a los colectivos sociales masculinos de las clases dirigentes y de raza blanca» (2012, p. 11), por lo que demanda «la necesidad de construir genealogías de mujeres y de recurrir a la memoria femenina frente a la memoria hegemónica, que ha sido habitualmente una memoria masculina y "blanca", mostrando la articulación/oposición de las categorías genero, clase y raza» (p. 13). Como aclara Alicia Redondo, las mujeres «no pasamos a lo escrito», es decir, «existimos en la realidad pero no formamos parte de la historia» (2001, p. 32), una idea que elabora Bonnie Smith en su clásico estudio sobre el género de la Historia (1998).
Mi colección de relatos es una forma de insistir no en «la espuma de la Historia» (Segura, 2001, p. 15), sino en las vivencias cotidianas que conforman una comunidad y la dotan de su propia idiosincrasia. Aclara Segura que, incluso a la hora de trazar historias alternativas para las mujeres, no es habitual usar fuentes literarias, aunque pueden servir de complemento de otro tipo de fuentes (p. 15). En mi relato busco, pues, historizar el mito y el cuento en un contexto posmoderno donde el concepto de verdad ha caído en desuso y, tal y como vengo argumentando, particularmente la noción de Historia ${ }^{5}$. Busco generar un mito de hermandad femenina, generador de nuevas identidades y realidades ficticias pero empoderadoras, que tenga un calado real entre las/ os lectoras/es. En este sentido, y como afirma de Urioste, aúno varias perspectivas concebidas como «marginales»: regionalismo, literatura popular y feminismo (1997, p. 100).

El predominio de mujeres protagonistas en mi colección, abre el debate de si nos encontramos ante un caso de literatura femenina. Con relación al antiesencialismo andaluz esgrimido en el apartado anterior, me gustaría

\footnotetext{
4 Según Cristina Segura, las fuentes literarias eran rechazadas por la Historiografía, «pues se consideraba que en ellas no podía haber nada utilizable para la elaboración histórica». En ellas se detectaba la "pura imaginación del autor, creación subjetiva de realidades imaginarias, que nada tenían que ver con la realidad histórica. La acusación de falta de objetividad invalidaba a estos escritos, incluso como complemento de los documentos considerados históricos» (2001, p. 13).

$5 \quad$ Ávila Rodríguez (2014), Vargas Quiroz (2014), Lorenzo-Feliciano (2016) y Páez Sandoval (2017), estudian los roles de género de las mujeres expuestos en su violencia y reconstruidos a través del papel de las «divas de barrio», La política de lo íntimo, lo abyecto como posibilidad y la mirada en diferentes autores y autoras.
} 
matizar la aplicación de esta etiqueta a mi escritura. Todavía en estudios relativamente recientes, como el de Alicia Redondo de 2001, se sigue cayendo, en mi opinión, en esencialismos biologistas relacionados con las cuestiones de género. Redondo define la literatura femenina como «la escrita por mujeres, pero quizá no toda y no solo», una literatura que debe tener al menos dos de las tres marcas femeninas que enumera: «que su autora sea una mujer y que el texto lleve marcas perceptibles de esta feminidad, aunque estas dos instancias se completan cuando la lectora es una mujer y su inferencia (interpretación) identifica, descodifica y acepta estas marcas de feminidad» (2001, p. 20). Este biologismo limitador de la autora, que confunde sexualidad con construcción de género, resulta contradictorio cuando afirma que entiende esta identidad «no de forma esencialista» (p. 43), pero nos regala afirmaciones tan tajantes como que «no leemos igual mujeres que hombres» (p. 21), la alusión a escritores varones como «escritores masculinos» (p. 35) o la propuesta de que, puesto que el adjetivo femenino es «central para referirse a nuestro sexo», debemos acostumbrarnos «a utilizar femenino en un senti- do amplio como sinónimo de obra de mujer» (p. 33), con el esencialismo que el mero uso en singular de este término conlleva y con la problematización que ha generado el concepto de «feminidad» en las distintas corrientes feministas. ${ }^{6}$

Por tanto, según las marcas femeninas de Redondo, mi escritura no puede ser etiquetada de «femenina», puesto que al ser un escritor varón no puedo compartir la experiencia y la sensibilidad de las escritoras. Sin embargo, los rasgos que Redondo (pp. 27-29) y Masanet (1998, pp. 35-41) enumeran como propios de la literatura femenina, impregnan mi colección y, en particular, el relato «Doce Mariposas»: una estructura que no sea lineal sino repetitiva, acumulativa, cíclica, disyuntiva; el tiempo cronológico es menos importante que el tiempo interior o tiempo de la vida; los espacios están marcados por la feminidad prefiriéndose los interiores frente a los exteriores; la nostalgia de la madre y del amor que simboliza; el uso de una gramática propia, a medio camino entre el lenguaje masculinista y el «lenguaje de la loca» de Gilbert y Gubar; la importancia otorgada al silencio y a lo imprevisto. Mi intención es transcender cuestiones esencialistas con relación al género: mis personajes son en su mayoría mujeres que luchan por ser escuchadas más allá del silencio al que han sido tradicionalmente recluidas en sus entornos rurales. ¿Esto convierte mi narrativa en una literatura femenina? Según Segura y Masanet, no; desde mi punto de vista, es una etiqueta de las muchas que pueden usarse para entender mi ficción, que está concebida con una clara intención subversiva para la lucha feminista y de género.

El relato «Doce Mariposas» entronca con el interés por recabar una Historia alternativa para las mujeres rurales. Como explica $\mathrm{M}^{\mathrm{a}}$ Dolores Ramos (2012, pp. 16-17), la atención a la historia de las mujeres surgió en Andalucía a mediados de los años setenta, estrechamente vinculada a los movimientos de oposición a la dictadura, la celebración del Año Internacional de la Mujer (1973) y la lectura, a veces clandestina, de algunos de los textos fundacionales del pensamiento feminista occidental en sus diferentes corrientes. Los textos de Rosa Capel, Mary Nash, Amparo Moreno, las hispanistas Geraldine Scanlon y Giuliana di Febo sobre el sufragio femenino, el papel de las mujeres en el movimiento

$6 \quad$ El biologismo de Segura se resume en este comentario: «Somos parcialmente diferentes desde el punto de vista fisiológico y material, ya que somos cuerpo sexuado; y ni siquiera es del todo igual nuestro cerebro lingüístico, ni, desde luego, nuestras hormonas, ni nuestra sexualidad que tiene la capacidad de crear vida con la maternidad. También hay diferencias desde un enfoque psicológico y experimental que facilitan la incorporación, como tema central de muchas novelas, de los sentimientos amorosos y las relaciones familiares de todo tipo, que se consideran el eje de la vida de una mujer» (2001, p. 24). 
obrero y la trayectoria del feminismo español abrieron el camino, mientras que los años 80 vieron el auge de los planteamientos feministas en las universidades andaluzas y en los 90 la historia de las mujeres y los planteamientos de género experimentan un gran avance en Andalucía. Hablando de las escritoras del XIX, Gloria Espigado alude al «emancipismo femenino decimonónico» (2012, p. 46) y concluye que:

Desposeídas de los derechos más elementales, condicionadas por el discurso de la domesticidad que trazaba un destino particular y diferente al del hombre, utilizaron las paradojas y las posibilidades abiertas por una expresión que no era ni mucho menos uniforme para desdibujar las fronteras entre los espacios públicos y privados, desarrollando estrategias individuales y colectivas que les permitieran realizar incursiones sobre ámbitos vedados. (pp. 46-47).

José Ortega considera que, a pesar de la observación de Carolyn Sachs de que «las mujeres rurales alimentan el mundo» (cf. García Lastra, 2008, p. 45), estas mujeres agrarias siguen siendo objeto de invisibilidad en el terreno historiográfico y de prejuicios y perspectivas de tipo agrocéntrico y androcéntrico (1981, p. 141). Igualmente, dichas mujeres adolecen de la imagen peyorativa y estereoti- pada de lo rural y se les percibe como «pueblerinas», «paletas» o «aldeanas», asociándolas con envejecimiento, retraso y actividad agraria (Maya, 2008, p. 28). Sin embargo, Valentina Maya propone romper con la imagen «monolítica, unitaria y compacta» de las mujeres rurales: «no podemos hablar de una mujer rural de manera genérica, dado que hay mujeres rurales que son distintas, dependiendo de la zona geográfica española» (2008, pp. 28-29). Se trata de sacar a la luz el asociacionismo de las mujeres rurales, tal y como reivindica Marta García Lastra en su apartado «participación sociopolítica», y hacer el esfuerzo por representar, tal y como propone Ruiz Muñoz, «una identidad andaluza más digna» (2008, p. 131).

El elemento costumbrista de mis relatos, se muestra sobre todo en la proyección de hablas rurales granadinas que no pretenden ser una caricatura, sino una reproducción verosímil del lenguaje de estos pueblos. Juan de Dios Ruiz Copete explicaba que «existe un lenguaje andaluz, o, si se prefiere, una semántica andaluza acorde con el paisaje del sur de España y en función de su realidad sociológica. Nuestro mundo [...] se manifiesta a través e una expresión literaria y artística absolutamente originales» (1977, p. 84). La crítica habla de retoques literarios en la reproducción del lenguaje del pueblo de escritoras como Fernán Caballero (Agúndez, 2017, p. 642). Evidentemente, en toda obra siempre hay una estilización literaria y mi intención se puede equiparar a la de Lorca, que era la de dar formas de perennidad a lo popular (Meg aunque e rescantan e los dilue busco tal vez se aplica mpresencia ineludible en mi narrativa, las Doce Mariposas, logra burlaías, 1985, p. 8). Virginia Guarinos hace un interesante estudio sobre la representación identitaria de mujeres andaluzas en el cine y se muestra pesimista en sus conclusiones:

No existen andaluzas en el cine independientes, con puestos de responsabilidad, sin alto sentido de la maternidad, dominadoras y con un acento andaluz de veras natural, lejos de los forzados acentos y léxicos. En fin, todo aquello que para una andaluza hace que las andaluzas en la gran pantalla se conviertan en seres incomprensibles y ridículos. La jornalera, la inmigrante, la estudiante, la ejecutiva, permanecen como mujeres oscuras en la sombra, detrás de las madres, vírgenes sacrificadas y sufridoras y de las fatales cigarreras. (1999, p. 116).

Esta percepción parece excluir la agencia de un determinado perfil de mujeres rurales que, debido a la orografía social de su pueblo, no pueden acceder a puestos de responsabilidad, abrazan la maternidad y se ex- 
presan con forzados acentos y léxicos. Las mujeres de «Doce mariposas» demuestran, como veremos, que es posible convertirse en agentes sin necesidad de rechazar los valores denunciados por Guarinos.

La temática que permea este relato es la violencia de género, pues, como veremos, tras la muerte de una de las protagonistas a manos de su marido, el resto de mujeres se sincera y confiesan el abuso que reciben en el ámbito doméstico. Como arguyen Virginia Maquieira y Cristina Sánchez, la violencia se percibe «como imposición de modelos socioculturales por parte del grupo dominante. Violencia que se invisibiliza y promueve la eficacia del silencio y la omisión para su perpetuación estructural en las sociedades democráticas» (1990, p. viii). Es, sin duda, en este marco donde se encuadra el relato y el que explica la leyenda silenciada que no puede contarse delante de los hombres. Celia Amorós habla de «pactos patriarcales» de distintos grados de tensión sintética: por un lado, los «pactos seriales» son los más laxos y «la misoginia que les es correlativa se expresa como violencia en forma de exclusión de las mujeres no especialmente represiva; es más bien [...] un "no tener en cuenta" constituyendo el topos de "lo no-pensado"» (1990, p. 11); por otro lado, los «grupos juramentados» son aquellos en que «la misoginia patriarcal se exacerba como violencia» $\mathrm{y}$, por tanto, «la mujer, como objeto transaccional de los pactos entre varones, cumple aquí una función especial en los rituales de confraternización de los pares: sin hablar ya de las ceremonias de rapto o de violación en grupo» (p. 12).

Críticas como Perla Hainovich, tratan de explicar la violencia de género con relación a la agresividad fomentada en la masculinidad hegemónica: «La frustración producida en el mundo exterior, la sensación de fracaso, el encontrarse sometido a una situación de subordinación, provoca en el hombre una necesidad de restituir la autoridad perdida y el único espacio en el que puede ejercer su poder es el ámbito domestico, sobre 'sus posesiones legítimas': la mujer y los niños» (p. 88). Es este sentimiento de posesión sobre la esposa, lo que refuerza, en opinión de Hainovich, "la descarga emocional en forma de agresión" (1990, p. 89). Hainovich explica que habitualmente se entiende que «es "responsabilidad" femenina el contener la agresividad del conflicto» (p. 90) y aunque reconoce que «el maltrato físico ha cambiado sus significados en el orden social, convirtiéndose en un valor condenable y desprestigiante [...] en el código de comunicación privado todavía persisten contenidos que lo hacen justificable y permisible en tanto intercambio de mensajes en el seno de la pareja» (p. 96).

Esta justificación de la violencia en el ámbito privado cobra un mayor sentido en el periodo histórico al que vagamente hace referencia «Doce mariposas»: el siglo XIX. Utilizando un ejemplo de denuncia de malos tratos interpuesta por una vecina del municipio salmantino de Sancti Spiritus en 1829, $\mathrm{M}^{\mathrm{a}}$ del Carmen Díez aclara que «el tratamiento que recibe esta conducta en aquella época es fundamentalmente el de ser un asunto personal que se arregla en el orden religioso, porque lo que más prima es la necesidad de vivir en paz y sin escándalo y en la unión matrimonial» (2008, p. 188). Habrá que esperar a la Ley de Violencia de Género de 2004 para que «este asunto dej[e] de ser un delito privado circunscrito al ámbito de lo familiar y se conviert[a] en un delito público» (p. 189). Eva Martín López aclara que no ha sido hasta bien entrado el siglo XX que la violencia de género se ha reconocido como tal violencia, sino más bien aceptada como parte del orden establecido: «Los malos tratos o el asesinato de las mujeres han sido tolerados por los poderes civiles y eclesiásticos y por la sociedad en general durante siglos» (2010, p. 5), situación que se reproduce en el relato que nos ocupa. Martín expone el 
caso de una denuncia de violencia de género en Cabra, a finales del siglo XVIII, que acaba con el aborto de la mujer. El hombre solo sería condenado si se demostraba la relación directa entre la agresión y el aborto, y el hecho de que este asunto se viera directamente y de forma secreta con el presidente de la Chancillería constata el carácter privado que se daba a estos actos contra las mujeres (p. 7).

La salida que encuentran las protagonistas de «Doce mariposas», es lo que se teoriza como grupos de autoayuda, que en palabras de Pérez Grande:

[...] constituyen un espacio terapéutico muy favorable para mujeres supervivientes de violencia de género, establecen una red social después del aislamiento al que han estado sometidas, un espacio de comprensión y apoyo mutuo entre mujeres que han pasado por la misma experiencia y un contexto de relaciones igualitarias frente a la relación de dominación del agresor. (pp. 339, 342).

En el caso de las protagonistas del relato, se trata de un grupo sin terapeuta que surge por iniciativa popular de varias personas con el mismo problema (Pérez Grande, 2010, p. 341) aunque, en lugar de estar marcado por la supervivencia de las mujeres que lo componen ( $p$.
345), surge precisamente a raíz de la muerte de una de ellas, que conduce al proceso de catarsis teorizado por $\mathrm{M}^{\mathrm{a}}$ Dolores Pérez Grande, según el cual «se habla de la experiencia vivida en un espacio de confianza compartido, lo que aumenta la conciencia de las propias percepciones, reacciones y sentimientos. Resulta una intensa experiencia emocional íntima y arriesgada que alivia, enriquece y aumenta la cohesión del grupo» (p. 350).

\section{«Doce Mariposas»: Leyenda y} cuento como Historia alternativa para las mujeres rurales andaluzas

El cuento de «Doce mariposas» cierra mi colección de relatos Hijas de un sueño (Esdrújula, 2017) con la recreación de una leyenda para el pueblo imaginario de Candiles. Esta leyenda se ubica vagamente en el siglo XIX y se ha transmitido desde entonces y en secreto de madres a hijas. La leyenda cuenta la historia de doce mujeres rurales que se reúnen diariamente en la iglesia para rezar el rosario como una forma de escapar del opresor ambiente doméstico donde, tal y como descubrimos, son víctimas de violencia de género.

El Jueves Santo, una de ellas, Cordelia, aparece muerta en las escaleras de su casa, aparentemente debido a un accidente, pero sus amigas concluyen que ha sido el resultado de una de las frecuentes peleas con su marido. Antes del entierro, las amigas se reúnen y urden un plan para escapar de sus casas y dejar de sufrir el maltrato de sus maridos. Durante la ceremonia, y puesto que Candiles se presenta como un pueblo muy beato cuyos feligreses beben tradicionalmente del cáliz bendito el Jueves Santo, las/os asistentes se quedan dormidos debido a un brebaje que las jóvenes han vertido en el vino, y ellas se vengan de sus maridos, fingen su propio asesinato, excavan sus tumbas simbólicas en el cementerio y se esconden en una cripta de la iglesia. El cuento acaba con la condena en efigie de estas mujeres por la Santa Inquisición, debido a la imposibilidad de localizarlas.

El relato empieza con una narradora que entronca con la literatura testimonial. Como afirma Jorge Narváez (1986, p. 235), la función testimonial «corresponde a una narrativa de no ficción, de historia verdadera - en que el término "verdadera" no tiene más pretensión que señalar la no ficcionalidad»y, como aclara Narváez, es una forma de «reproducir la realidad de forma imaginaria mediante elementos "históricos-verdaderos" que reordenan y transforman dicha realidad, la sociedad y los procesos históricos» (p. 240). 
Aunque, en este cuento, la leyenda se presenta como un mito de Candiles, la narradora imprime verosimilitud a su narración con esta función testimonial: «Después de varios siglos, la excomunión de las Doce Mariposas parece una trola, pero yo vi ese documento con mis propios ojos» (2017, p. 139). De este modo, y aunque puede concebirse como una narradora poco fiable al ser parte de la comunidad de madres e hijas que transmiten en silencio esta leyenda, se encarga de romper la delicada línea que separa ficción y realidad, y así comienza su narración: «Érase una vez que nunca fue, o eso dicen» ( $p$. 139).

El relato, por tanto, combina la indeterminación temporal del cuento de hadas (y como veremos, la base de esta leyenda es la reescritura de un cuento tradicional), lo que Eliade Mircea (cf. Kermode, 1970, p. 39) o Marie-Louise Von Franz (1982, p. 27) denominan illus tempus (eternidad atemporal o ahora y siempre) con una sutil referencia a un contexto histórico determinado: la Andalucía de principios del siglo XIX bajo el reinado de Fernando VII, cuando la Inquisición estaba a punto de extinguirse.
Mito e Historia se combinan para sugerir un espacio literario alternativo de reivindicación histórica. El pacto de silencio entre las mujeres de la comunidad en relación a la rompedora leyenda feminista de las Doce Mariposas, es una clara indicación del entorno patriarcal en el que se gesta la historia, que esgrime la misma misoginia que antaño, incluso dos siglos después. La misoginia actual; sin embargo, no impide que las mujeres defiendan su peculiar memoria histórica, carente de credibilidad pero poderosa tras el silencio, muy en la línea de la demanda de Ramos Palomo (2012, p. 13) de construir genealogías de mujeres y recurrir a la memoria femenina frente a la memoria hegemónica: ${ }^{7}$

En Candiles se habla de leyenda y hay que contarla en voz baja y nunca, nunca, delante de los hombres, porque les hierve la sangre y pegan puñetazos en la mesa.

— ¿Eso son patrañas! —dicen.

Pero nosotras sabemos que no y, cada noche, cuando arropamos a nuestras hijas, les contamos la historia para que no caiga en el olvido. ( $\mathrm{p}$. 139).
Precisamente, mientras que críticos como Maya hablan de «mitos de cómo la mujer en general y la mujer rural en particular debían ser o comportarse», que se transmiten «a través de la cadena generacional: abuela-madre-hija» (2008, p. 26), las mujeres de este cuento mantienen esta cadena generacional pero rompiendo estereotipos femeninos rurales. Por tanto, frente a la percepción generalizada de críticas como Redondo de que las mujeres «no pasamos a lo escrito», que mencionábamos antes, este cuento convierte una tradición oral silenciada en un formato textual escrito que, junto a la carta colectiva de denuncia de violencia de género que redactan las mujeres protagonistas con la ayuda de la única que sabe escribir, contribuye a que las mujeres rurales pasen a lo escrito y tengan un impacto en la Historia a través de las/ os lectoras/es. Mi experimento narrativo en «Doce mariposas» parte pues del cuento y la leyenda como espacios alternativos para reinventar una historia tradicionalmente percibida como irrefutable, y dotar de visibilidad textual a un grupo de mujeres sistemáticamente silenciadas en su anonimato histórico.

$7 \quad$ De Urioste habla de un «pacto de silencio» para explicar «la ruptura del pueblo andaluz con el pasado» y «como resultado de la política y cultural centralista del general Franco» (1997, p. 100). Ese ambiente de represión política se puede extrapolar al relato, donde las mujeres han de ocultar su rebeldía ante un sistema patriarcal totalitario que, obviamente, tiene un efecto violento en las mujeres. Hablando de la anciana Bernardina y su revelación de la existencia «real» de las Doce mariposas, la narradora dice: «Yo creo que le callaron la boca de mala manera" y añade: “Es mejor dejar las cosas como están» (p. 140). 
La base de este cuento es la intertextualidad con fines subversivos. Los dos hipotextos principales, siguiendo la terminología de Gerard Genette en Palimpsestos para definir las relaciones de hipertextualidad, son el cuento de hadas y la Biblia. Para otorgar a la leyenda de las Doce Mariposas un carácter mítico y atemporal, el relato sigue la estructura del cuento de «Las doce princesas bailarinas» de los Hermanos Grimm. En dicho cuento, las doce hijas de un rey escapan cada noche a otro reino a bailar con unos príncipes y regresan con los zapatos desgastados cada mañana. El rey se percata de que sus hijas esconden algo y dicta que quien descubra el secreto de las princesas en tres días se casará con una de ellas o, de no hacerlo, será ejecutado. Varios príncipes lo intentan, pero fracasan porque las princesas los drogan con vino y se quedan dormidos. Un día, una bruja se cruza con un soldado y le ofrece una pócima para contrarrestar el efecto narcótico del vino y una capa de invisibilidad para seguir a las princesas sin ser visto. De este modo, las persigue cada noche y guarda evidencia de las escapadas, hasta que finalmente las delata y se acaba casando con la mayor de ellas.

«Doce mariposas» supone una reescritura de este cuento con una revisión de roles de género y de clase. ${ }^{8}$ Se trata, pues, de superar los cuentos infantiles tradicionales que, como argumentan Laura y Cristina Filardo, «fomentan una visión estereotipada y reduccionista de los sexos» (2008, p. 270). Las princesas son reemplazadas por mujeres rurales anónimas, víctimas de violencia de género, que escapan de la realidad a través del cuadro de las Ánimas Benditas de la iglesia, que las conduce a un espacio liberador, sin la presencia de los hombres. Mientras que en el cuento de los Hermanos Grimm, las princesas escapan para bailar con sus príncipes («hetero-realidad», Raymond, 1986, p. 3); las protagonistas de «Doce mariposas»» escapan de la estructura patriarcal, para fundar una sororidad que se articula sin la presencia de los hombres («afectividad de mujeres», Raymond, 1986, p. 7).

Una vez en su escondite, todas ellas comparten secretos sobre sus abusos, bromean y hasta bailan entre ellas. La unión la resume Maruja cuando dice: «Niñas, menos mal que estamos juntas» (p. 147). Al igual que el vino narcótico de los Hermanos Grimm, en «Doce mariposas» este vino aparece ligado a una eucaristía y al sueño colectivo del pueblo, que permite a las mujeres escapar. Mientras que el soldado del cuento de los Grimm traiciona a las princesas para conducirlas al sino patriarcal del matrimonio, la figura equivalente en «Doce mariposas» es Sagrario, una de las mujeres mayores del rosario, muy cercana a las jóvenes, que se siente traicionada cuando estas escapan sin ella. En un momento del relato, está a punto de acusarlas ante la autoridad (y cumplir así el papel del soldado al conducir a las mujeres de vuelta a sus maridos); sin embargo, finalmente comulga con las jóvenes y acaba formando parte del grupo de las mariposas.

Frente a esta comunidad pseudo-religiosa (que explicaré más adelante), la imagen final de estas mujeres dista mucho de las princesas estereotipadas de los Grimm y todas ellas se alzan como mujeres fatales, liberadas de sus maridos, cuyas siluetas de brujas danzan cual aquelarre entre las tumbas (p. 151). La crítica de clase que evoca este relato entronca con la de Margaret Atwood en su irreverente y paródica versión de $L a O d i$ sea, The Penelopiad, narrada por Penélope y las doce doncellas asesinadas. Esta mujeres comparten con las doce doncellas de Atwood, aparte del mismo simbolismo, la denuncia de la violencia de género a través de la parodia y del motivo del

8 En «Doce mariposas», hay varias referencias directas al cuento de los Hermanos Grimm: «antes de amanecer, regresaron con zapatos desgastados y ojos de ensueño» (p. 142); «Se acabaron los bailes en otros reinos» (p. 149). 
baile, pues los pies colgantes e inertes de las doncellas asesinadas se convierten en un baile hipnótico que persigue a los maltratadores de por vida.

En «Doce mariposas», las mujeres rurales consiguen sacar a la luz su asociacionismo, tal y como reivindica García Lastra. La rebeldía de este grupo se sugiere al principio del relato a través de la comparación de los personajes con avispas: «sus voces agudas y temblorosas sonaban a avisperos apedreados»; "Al caer la tarde, la iglesia albergaba en sus entrañas los zumbidos de aquellas mujeres, tal vez provocados por un hambre de sueños» (p. 140). Este cuento supone un viaje de vuelta al orden semiótico de Julia Kristeva, al espacio maternal donde el cordón umbilical marca un lazo de por vida entre madres e hijas, simbólicamente reflejado en la tradición familiar que permite la continuidad de esta leyenda silenciada. La maternidad de una de las jóvenes, Soco, sirve para transcender los límites biológicos y conectar a todas estas mujeres a través de una maternidad simbólica que las empodera como grupo. De este modo, «el bebé de Soco saltaba dichoso en el seno de todas» (p. 140) y, aunque Sagrario «acariciaba su vientre baldío» (p. 141), sugiriendo que pertenece a una generación más anciana ajena a esta opción biológica, más adelante se percibe su conexión con el bebé: «El llanto de la niña se le clavó como un cuchillo, como si se la hubieran arrebatado de las entrañas» (p. 149).

La maternidad simbólica y compartida de este grupo, sugiere la conexión semiótica grupal y permite construir una nueva genealogía de mujeres según la afectividad teorizada por Raymond, que escapa a las limitaciones patriarcales. En el relato, el orden semiótico de Kristeva aparece claramente ligado a los conceptos de «abyección» (lo que desestabiliza la identidad, el sistema y el orden; lo que no respeta bordes, posiciones y reglas; Kristeva, 1982, p. 4) y de «cripta» (un lugar presente y ausente en el mapa, cuyas coordenadas no pueden rastrearse; Hi1lis Miller, 1994, p. 6). En este sentido, la maternidad simbólica compartida de estas mujeres («La recién nacida ya era hija de todas», p. 146) acontece en el espacio secreto tras el cuadro de la iglesia, la cripta derridiana que permite la revelación de los secretos de abuso y da oficialmente comienzo a esta sororidad: «Al calor de la vela recién prendida, compartieron secretos que jamás habían contado» ( $\mathrm{p}$. 146). El cambio en Sagrario está marcado igualmente por este impulso semiótico, cuando, sentada para denunciar a las jóvenes, miró el cuadro de la Virgen y notó que sus ojos «se le clavaban en el pecho como las manitas de su hijo» (p. 149).
El segundo hipotexto de este relato, es el Nuevo Testamento y, en particular, la comunidad cristiana de los doce apóstoles. El asesinato de Cordelia el Jueves Santo es indicativo de la Última Cena y cobra un valor simbólico ineludible. El personaje de la joven asesinada, Cordelia (con ecos de la tragedia de Shakespeare El rey Lear), se alza como una figura mesiánica que muere por sus compañeras, pues es ella quien les enseña la gruta secreta que las conduce a la salvación de sus maridos, irónicamente tras el cuadro del Purgatorio (p. 142), y la que les proporciona un cáliz sustituto de madera ( $\mathrm{p}$. 144). La asociación de Cordelia con el cordero divino queda patente con la irrupción en la iglesia de un borrego, que bala ajeno a la solemnidad del acto $\mathrm{y}$, como las jóvenes durante la misa, se siente abandonado por el Padre (p. 143).

Las imágenes transgresoras contra la institución de la Iglesia, se suceden en el relato para ofrecer una alternativa espiritual que no victimice a las mujeres. Según cuenta la tradición, el rosario se remonta a las mártires cristianas que morían en tiempos romanos (hay una referencia al «circo romano» para referirse al pueblo enjuiciador, p. 148), y que portaban coronas de rosas cuyos pétalos se recogían del suelo tras la muerte; por cada rosa, se rezaba un salmo. Aquí, las rosas forman ma- 
riposas y alzan el vuelo en señal de liberación.

La crítica a una institución trasnochada y patriarcal, se refleja en varios episodios. Durante la celebración de la eucaristía del Jueves Santo, el rito de la Santa Cena se describe con la siguiente teatralidad grotesca, exponiendo una masculinidad solemne, artificial y terrorífica: «Por el largo pasillo de la iglesia desfilaron doce hombres con capas anudadas al cuello, hábito blanco y el rostro cubierto por máscaras hieráticas y brillantes. Los niños empezaron a llorar abrazándose a sus madres y los varones se alinearon ante el altar con un cirio en la mano luciendo prominentes barbas teatrales» (p. 143).

Por otro lado, durante el acto condenador del Santo Oficio, las asociaciones de sus representantes con figuras demoníacas sugieren una crítica mordaz de la bondad, justicia y moralidad de esta institución: «El cura lanzó una mirada diabólica a toda su grey» (p. 148); «Esa noche las antorchas ardieron en un acto de magia negra y las coronillas de las autoridades brillaron con el fuego de la vergüenza» ( $p$. 150). Tal y como teoriza Amorós, en los grupos juramentados de hombres se desencadena habitualmente la «caza de brujas», de la que ella habla en sentido metafórico. Sin embargo, en este relato es una caza real que Amorós explica porque la bruja existe «como analogado supremo planeando constitutivamente sobre el pacto mismo en tanto que amenazado» (1992, p. 15). ${ }^{9}$

De este modo, aunque las rebeldes son sistemáticamente presentadas como brujas ( $\mathrm{p}$. 150) e incluso perpetran un aquelarre entre las tumbas ( $p$. 151), esta imagen de magia negra adquiere toda su fuerza en relación al grupo eclesiástico de la Inquisición. La supuesta brujería de estas mujeres se tinta de una parodia y subversión similares a las de las doncellas asesinadas del libro de Atwood. Sin embargo, al contrario que en el cuento de los Grimm y la novela de Atwoord (donde Penélope traiciona a sus doncellas para salvar el pellejo), en «Doce mariposas» no aparece la figura de Judas. Es cierto que Sagrario está a punto de delatar a las mujeres, pero finalmente no lo hace y acaba compartiendo con Cordelia el rol mesiánico que implica su nombre. Es una forma de sugerir una fluidez funcional en esta sororidad donde todas colaboran por igual en una liberación colectiva.

Por el contrario, la comunidad de hombres se expone en el relato como una falsa homosocialidad que promueve la violencia hacia las mujeres. Pequeñas pinceladas sugieren la agresividad masculina como herramienta de empoderamiento. Cuando escuchan la leyenda de las mujeres rebeldes, «les hierve la sangre y pegan puñetazos en la mesa» (pp. 139, 151) y se nos dice que, durante la procesión del Santo Rosario, los hombres a veces «acababan a farolazo limpio» (p. 141). En este contexto, no nos sorprende, por tanto, la violencia doméstica. Aunque el marido de Cordelia explica su muerte rodando por las escaleras como resultado de su sonambulismo (p. 142), las jóvenes remiten a episodios de marcas de violencia: «Recuerda que día sí y día también venía con cardenales por tol cuerpo y a veces hasta con un ojo morao» (p. 142).

Esta situación de violencia se extiende a todas las mujeres y se reviste del código privado del que habla Haimovich, pues, como dice Dorita, «Toas sabemos mu bien lo que pasa en nuestras casas, aunque no diga-

\footnotetext{
$9 \quad$ Amorós elabora la explicación de esta amenaza: «Por ello las reuniones de brujas solas, en la medida en que puedan llegar a cobrar importancia o alcanzar algún poder, son percibidas como aquelarres conspiratorios y, fundamentalmente, como aliadas del enemigo; en el centro hemorrágico por el que el grupo juramentado pierde el control de la situación, siempre habrá que chercher la femme» (1992, p. 15).
} 
mos ni mu» (p. 142). Se trata, por tanto, de un claro ejemplo de «pacto patriarcal», tal y como lo explicaba Amorós, que constituye un grupo juramentado donde la misoginia patriarcal se exacerba como violencia, una violencia soterrada y doméstica, en tanto que generalizada por el sistema. De hecho, en el relato hay evidencia de que los malos tratos e incluso el asesinato de las mujeres son tolerados por los poderes civiles y eclesiásticos, y por la sociedad en general, como teorizaba Martín. Aun denunciando esta violencia públicamente a través de una carta colectiva, la Iglesia en la figura del sacerdote que lee el evangelio de la mujer adúltera habla de «un día de vergüenza para este pueblo» y condena la actitud de estas mujeres que «han rechazado el modelo de la Virgen» y se han saltado la ley de que «el matrimonio es un sacramento sagrado y las esposas han de obedecer a sus maridos» (p. 148). Esta violencia demuestra ser, como vaticinaba Díez, «un asunto personal que se arregla en el orden religioso, porque lo que más prima es la necesidad de vivir en paz y sin escándalo y en la unión matrimonial» (2008, p. 5).

Ante este abuso institucional, el grupo de mujeres «urde» un plan (p. 142) que supone una inversión paródica y eficaz denuncia de la violencia machista.
Tras dormir con una pócima a toda la grey, «[1]as jóvenes dejaron a sus esposos completamente desnudos y, con tizones de la lumbre, les dibujaron cardenales por todo el cuerpo, parecidos a los que ellas ocultaban bajo sus vestidos» (p. 144). Acto seguido, se entregan a un acto performativo donde revisan paródicamente los roles de género con una clara intención reivindicativa: «Mariquita le pintó un bigote a la hija del cartero, que se reía de ella y era más pava que un perrito con lazo, y Carmela maquilló como una puerta al panadero, que todos los días le tocaba el culo por la calle» ( $p$. 144). En esta línea teatral y performativa, las mujeres utilizan sangre de cerdo (con sus asociaciones sacrificiales) para marcar de rojo sus hogares y dejar «un mensaje ensangrentado en el muro de la iglesia. Estamos muertas» (p. 145). La crítica a la institución de la iglesia queda clara en este pasaje. Este grupo provoca su propia muerte simbólica que conduce a su liberación. Así, tras este episodio, «[t] odas rompieron a reír y unieron sus manos»y y adoptaron roles tradicionalmente asignados a los varones: «Borrachas como cubas» con «las escopetas de sus maridos» (p. 145). El triunfo temporal frente al patriarcado es ineludible. La corporeidad de la sangre funciona como un elemento abyecto que, frente al raciocinio patriarcal, expone públicamente el acto de violencia, como la sangre restregada en las paredes de las casas que se percibe como una «humillación» (pp. 145-146). Estas mujeres convierten el acto privado de violencia doméstica en un acto público, una acción que hasta la propia Iglesia quería ocultar.

La imagen de la mariposa es central en el relato. Para empezar, esas mariposas representan a un grupo de mujeres analfabetas que, al no saber ni firmar, utilizan este símbolo para proyectar su alma libre en el papel. En la carta redactada por Adela, la única que sabía escribir por ser la hija del maestro del pueblo, todas empaparon en tinta las puntas de sus dedos, «dibujaron mariposas negras y los deditos de Mari Luz recordaron a Cordelia. Las doce mariposas revolotearon sobre el papel» (p. 147). Aunque el color negro puede sugerir el luto por el asesinato de Cordelia, la tinta finalmente triunfa y permite narrar la historia de abuso y plasmarla para siempre en un papel. Esta liberación de las mariposas surge en el pasaje en que Sagrario se reconcilia con ellas y es admitida en el grupo, sugiriendo la hermandad de mujeres de distintas generaciones: «las jóvenes se asomaron al balcón batiendo sus manos como mariposas. Sagrario recibió el saludo emocionada y elevó las manos, 
que comenzaron a volar» ( $\mathrm{p}$. 150). La imagen que cierra el cuento es la de sus tumbas marcadas con «mariposas ensangrentadas», que conducen a las siluetas de unas brujas bailando entre las tumbas (p. 151). A través de esta performatividad, denuncian la muerte de Cordelia, pero transcienden el drama para volar lejos como grupo. El final queda abierto: según algunas versiones, fueron capturadas y castigadas; según otras, volaron bajo la luna y fueron libres.

\section{Conclusión: un sueño muy real}

El presente trabajo me ha permitido, desde una perspectiva crítica, reflexionar sobre mi primera colección de relatos, Hijas de un sueño (2017). Sin duda, mi localización en el Sur peninsular y mi trayectoria en Estudios de Género, revelan el calado ideológico presente en mi obra y me han permitido dialogar con mi propia escritura creativa.

Las mujeres andaluzas de Hijas de un sueño no renuncian, en su mayoría, al espacio femenino forjado para ellas en las sociedades rurales patriarcales que las acogen. Sin embargo, se alzan como personajes independientes y fuertes que reinventan y negocian ese espacio de fe- minidad desde la complejidad de caracterización y sin caer en forzados acentos y léxicos o mera caricaturización.

No renuncio a los elementos costumbristas que moldean la identidad de los personajes, pero no constituyen una esencia identitaria, sino que forjan una personalidad que transciende el localismo andaluz y entronca con las grandes preocupaciones universales que apuntan el camino hacia el que debemos dirigirnos para romper esencialismos ontológicos limitadores. Reivindico, por tanto, una reescritura de la feminidad, y las mujeres oscuras de las que habla Guarinos se convierten, espero, en seres de luz en el pueblo que he llamado metafóricamente Candiles. Como arguye Guarinos:

[...] cuando algunos de estos personajes consigue desprenderse de sus características arquetípicas andaluzas todavía les queda otra barrera que superar, la del rol de mujer. Y aunque en sí los personajes como mujeres parezcan querer desprenderse a su vez de ese otro esquema femenino, son los otros personajes, mujeres y hombres, en su roles patriarcales tradicionales, los que no las ven de ese modo. Existe una resistencia diegética que anula la posibilidad de mujeres con existencia de mujer y sin tópicos de mujer y con existencia de andaluzas sin tópicos de andaluzas. No encontramos por completo y con nitidez la excepción que confirme la regla. (1999, p. 126).

En «Doce Mariposas», el entorno rural conduce a la limitación $\mathrm{y}$ al asesinato simbólico de las mujeres rebeldes, pero hay un fragmento en el que el pueblo parece quedar exonerado: «El pueblo profirió insultos a las llamas del pecado, tal vez porque comulgaba con las autoridades o para guardar las apariencias» (p. 151). Mientras que aquí no queda claro si el pueblo actúa por miedo a la institución del Santo Oficio, en el resto de la colección aparece mayormente dibujado como un espacio de liberación que permite reinventar roles de género más allá de los prejuicios. Es cierto que los personajes de Candiles no logran escapar totalmente del entorno patriarcal, pero, gracias al vehículo de la escritura, podemos vislumbrar un grupo de mujeres empoderadas que, como es el caso de las Doce Mariposas, logra burlar el sistema patriarcal y transciende los tópicos andaluces para crear una historia universal de auto-empoderamiento, un sueño ficcional que araña la realidad, o lo que entendamos por ella. 


\section{Doce mariposas}

(Relato extraído de la obra de Gerardo Rodríguez Salas, Hijas de un sueño. Granada: Esdrújula ediciones, pp. 139-152)

\section{I}

Érase una vez que nunca fue, o eso dicen.

En Candiles se habla de leyenda y hay que contarla en voz baja y nunca, nunca, delante de los hombres, porque les hierve la sangre y pegan puñetazos en la mesa.

— ¡Eso son patrañas! —dicen.

Pero nosotras sabemos que no y, cada noche, cuando arropamos a nuestras hijas, les contamos la historia para que no caiga en el olvido.

Después de varios siglos, la excomunión de las Doce Mariposas parece una trola, pero yo vi ese documento con mis propios ojos.

- No lo toques ni se lo cuentes a nadie — me dijo Bernardina mirando con recelo a su alrededor.

La anciana limpiaba la iglesia y no metía la lengua en paladar, pero guardaba ese secreto como oro en paño. Al día siguiente le dio un tic en el ojo y no volvió a salir al tranco de la puerta. Yo creo que le callaron la boca de mala manera.

Es mejor dejar las cosas como están.

Dice la leyenda que un grupo de mujeres se reunía en la iglesia para rezar el rosario. Casi todas eran mayores y les faltaba poco para irse al otro barrio. Cuando entraban por las puertas, un mar de luto inundaba la parroquia y sus voces agudas y temblorosas sonaban a avisperos apedreados. Las doce jóvenes, en cambio, despintaban la negrura con brochazos de color y soportaban los misterios y las mantellinas, porque el rosario les daba un respiro de sus maridos.

Sagrario era famosa en el lugar por ser más beata que nadie y saberse los rezos sin titubeos. Parecía habérsela tragado un cuervo, pues la cubría un mantón sombrío con flecos alargados que tapaban sus manos cadavéricas y caían como gusanos por debajo de las rodillas. Un pañuelo bruno se enroscaba en su cuello ocultando su roete y su nariz aguileña le confería la autoridad de una vestal octogenaria o de una bruja. Sin embargo, tras su dura coraza, sentía predilección por las muchachas.

Al caer la tarde, la iglesia albergaba en sus entrañas los zumbidos de aquellas mujeres, tal vez provocados por un hambre de sueños. Durante los misterios dolorosos, las ancianas caían en trance, algunas con los ojos vueltos mientras sus voces entonaban la crucifixión del Salvador. Las jóvenes, por el contrario, preferían los gozosos y, cuando recitaban La Visitación, compartían sonrisas cómplices y señalaban con los ojos la barriga de Soco, una primeriza a punto de salir de cuentas y la única madre, todavía, del grupo de recién casadas. Cada tarde se reunían como hermanas y el bebé de Soco saltaba dichoso en el seno de todas. A veces Sagrario les lanzaba una mirada inquisidora y las jóvenes daban un respingo mientras ella acariciaba su vientre baldío. 
El rosario semanal era más de andar por casa, aunque las jóvenes aprovechaban para ponerse guapas y echarse piropos, porque sus maridos no les hacían el menor caso. Eso sí, demasiado maquillaje podía levantar el recelo del macho, así que se acicalaban con discreción. Estas veladas eran ensayos de fe antes de la puesta en escena del domingo, cuando hombres y mujeres paseaban el Santo Rosario por las calles, primero ellas, que a media tarde se convertían en teloneras. Todas coincidían en que los hombres cantaban mejor, aunque a veces el alcohol hacía de las suyas y acababan a farolazo limpio.

El rosario comenzaba en la plaza de la iglesia y la gente encendía velones y candiles a su paso.

- ¡Viva María, viva el Rosario y el Santo Domingo que lo ha fundado!

El recorrido acababa con la veneración del cuadro de la Santísima Trinidad. Dolorcicas adoptaba un aire divino contando la historia, como si un foco iluminara su rostro traspasado. Según ella, un día Candiles amaneció gris y, sobre un montículo, una nube depositó el cuadro, que parecía recién pintado. Envuelto en una túnica roja, el Hijo llevaba una cruz de madera alzando la mano derecha en señal de curación. Su Padre portaba orbe y cetro lanzando al vacío una miraba perdida $y$, en mitad, volaba triunfante la paloma, que esparcía su luz rodeada de un coro angelical. El cuadro era majestuoso, aunque los rostros destilaban tristeza y condena y evocaban una obra de teatro con malos actores.

El Jueves Santo una de las jóvenes amaneció muerta en el rellano de la escalera.

— Ha sío un accidente — dijo el marido aclarando que su esposa era sonámbula.

Pero sus amigas no creyeron una palabra y se reunieron en la sacristía horas antes del entierro.

- Se ve que estaba amorataíca después de roar por tantísimo escalón.

- ¡Venga ya, Dorita! ¿Y tú te lo crees? Recuerda que día sí y día también venía con cardenales por tol cuerpo y a veces hasta con un ojo morao.

-Yo no puedo callarme más la boca - dijo Adela entre lágrimas-. ¡A este paso nos matan a toas!

Le temblaron las manos y el pánico brotó de sus ojos.

-Yo desde luego no me trago lo de las escaleras - respondió Dorita-. La Adela tiene razón. Toas sabemos mu bien lo que pasa en nuestras casas, aunque no digamos ni mu.

- A la Cordelia la ha matao su marío - se apresuró a decir Maruja- ¿Os acordáis del escondite que nos enseñó hace unos días?

Todas giraron la cabeza hacia un cuadro enorme de las Ánimas Benditas y recordaron su primera excursión por la gruta oculta, que conducía a la cúpula de la iglesia. Lideradas por Cordelia, cruzaron el cuadro del Purgatorio y viajaron a otro Reino. Allí bailaron y rieron y maldijeron y hasta bebieron aguardiente; $\mathrm{y}$, antes del amanecer, regresaron con zapatos desgastados y ojos de ensueño.

- Se lo debemos a ella —añadió Soco-. Yo no quiero que mi niño nazca en un mundo tan feo. ¡Vámonos esta misma tarde! ¡En el entierro!

Y las jóvenes urdieron un plan.

II

En la iglesia no cabía un alfiler. El silencio inundaba el recinto y el féretro de Cordelia presidía a los pies del altar. Sobre el ataúd yacían un lirio blanco y un rosario de huesos de Getsemaní y las llamas de los cirios bailaban al son de las plañideras. El incienso olía a tragedia, tan denso que las jóvenes casi se desmayan. En el altar ardían dos enormes braseros que los asistentes 
contemplaban helados desde las sillas. Las jóvenes se sentaron separadas y compartieron miradas cómplices pero inquietas. Mientras el séquito de papagayos balbuceaba las palabras en latín de un cura que les daba la espalda, las muchachas contemplaron el ataúd y se sintieron abandonadas por el Padre.

El entierro de Cordelia no alteró la ceremonia del Jueves Santo. Por el largo pasillo de la iglesia desfilaron doce hombres con capas anudadas al cuello, hábito blanco y el rostro cubierto por máscaras hieráticas y brillantes. Los niños empezaron a llorar abrazándose a sus madres y los varones se alinearon ante el altar con un cirio en la mano luciendo sus prominentes barbas teatrales. Al ritmo de antífonas entonadas por el coro, el cura se desprendió de la casulla y, arrodillándose, comenzó a lavar los pies de sus feligreses con ayuda de los monaguillos.

Cuando estaba a punto de acabar el rito, la puerta de la iglesia se abrió de un portazo. Un borrego entró desbocado y se coló entre las piernas de una beata, que pegó un chillido mientras el animal se estampaba contra el ataúd. Las amigas se miraron extrañadas. Un hombre corpulento agarró al borrego por las patas $\mathrm{y}$, echándoselo a la espalda, caminó hacia la calle. El balido era tan agudo que los fieles se taparon los oídos hasta que se perdió en la lejanía.
El cura reanudó la ceremonia $y$, finalizado el lavatorio, se enjuagó las manos con jabón de aceite. Las amigas cruzaron de nuevo las miradas. Había llegado el momento. Candiles era un pueblo muy beato $\mathrm{y}$, para conmemorar la Última Cena, el cura ofrecía la comunión bajo las dos especies el Jueves Santo. Uno tras otro, los fieles recibieron el Cuerpo y la Sangre de Cristo y volvieron a sus asientos, todos menos ellas. El cura regresó al altar, guardó un minuto de silencio y cayó desplomado entre los gritos de los monaguillos, seguido del resto de asistentes, que se desmoronaron como fichas de dominó. Al instante, los niños rompieron a llorar y las jóvenes los encerraron en la sacristía, donde habían preparado bandejas de torrijas y pestiños.

Como predijo la curandera, la pócima en el vino funcionó de maravilla y todos cayeron dormidos como lirones. Las jóvenes dejaron a sus esposos completamente desnudos y, con tizones de la lumbre, les dibujaron cardenales por todo el cuerpo, parecidos a los que ellas ocultaban bajo sus vestidos.

- ¡El mundo a nuestros pies! - gritó Consuelo impulsada por el furor del momento.

Liberadas, corretearon por la iglesia saltando entre los cuerpos. Mariquita le pintó un bigote a la hija del cartero, que se reía de ella y era más pava que un perrito con lazo, y Carmela maquilló como una puerta al panadero, que todos los días le tocaba el culo por la calle. Maruja apagó el cirio pascual, quitó el mantel y se quedaron todas en silencio. Al rato, sacó del bolso una copa de madera que le había dado Cordelia y la sustituyó por el cáliz del sagrario, que algún día venderían para largarse del pueblo. Antes de salir de la iglesia, abrieron la tapa del ataúd y se despidieron de su amiga con un beso en la frente.

Ligeras como plumas, se fueron a la casa de Adela, que sacó del armario un cubo con sangre de cerdo y, tras marcar de rojo sus hogares, dejaron un mensaje ensangrentado en el muro de la iglesia.

\section{Estamos muertas.}

Adela le robó a su marido la bota de vino $\mathrm{y}$, entre trago $\mathrm{y}$ trago, las mujeres subieron al cementerio, donde cavaron sus tumbas.

-Compañeras, ya estamos muertas — dijo Adela con sorna.

Todas rompieron a reír y unieron sus manos.

- ¡Madre del cordero, quién nos lo iba a decir! — gritó Puri.

Borrachas como cubas, repartieron la comida y el dinero ro- 
bado y se colgaron las escopetas de sus maridos de vuelta a la cúpula de la iglesia.

—¡Deprisa! -invocó Maruja- Tenemos que escondernos antes de que se despierten. Cuando se olviden de nosotras, nos iremos pa siempre de este pueblo.

III

Candiles no volvió a ser el mismo. El pueblo limpió la vergüenza, pero la humillación se quedó restregada en las paredes de las casas. Semanas más tarde, Soco dio a luz en la cúpula con la ayuda de Angustias, que se hizo comadrona de la noche a la mañana.

- iOtra niña! — gritaron cuando Mari Luz salió del vientre de su madre.

—Esta niña tendrá otra vida, como yo me llamo Soco.

La recién nacida ya era hija de todas. Al calor de la vela recién prendida, compartieron secretos que jamás habían contado.

-A mí me desvirgó el primo francés de mi marío —soltó Pepa a bocajarro después de zamparse una copita de aguardiente- Anda que si se entera mi Antonio...

-Pues no se habría casao contigo - la interrumpió Manue- la- y te habrían mandao al convento con tu Clotilde.

-Pues mi hermana estuvo a punto de pillarnos con las manos en la masa -continuó Pepa-. ¡No veas la perejila! El muchacho escondío debajo de la cama y ella que no se iba.

- Te tenían que haber atao corta, ¡so marrana! - bromeó Maruja.

Y se echaron a reír.

-Pues tú dirás lo que quieras, pero es lo único bueno que me voy a llevar al hoyo. Ese sí que me trató como a una reina. Me decía unas cosas en francés mientras me trasteaba ahí abajo...

—iQué romántica, Pepa! —exclamó Maruja.

Más carcajadas. El aguardiente ya corría por sus venas.

-Yo no me acuesto con mi marío y por eso me pega tanto zampó Consuelo.

— ¡Madre del amor hermoso!

- ¿Y eso, cariño? ¿Es que no te motiva? - preguntó Manuela.

—QQué va, mujer! —añadió Consuelo con cara compungi$\mathrm{da}-$ Es que no soporto que me toque ningún hombre. Cuando era chica mi tío Aniceto me lle- vaba al establo a ver los conejos y allí mismo me manoseaba y me decía que me rajaba entera como abriera el pico. En mi casa lo adoraban tos y pensaban que era un santo.

- A mí me pasaba lo mismo confesó Puri medio borracha-. Mi abuelo me llevaba al campo y me hacía unas cosas mu feas.

Dorita y Mariquita se unieron a las confesiones y mencionaron a un hermano y a otro tito.

— ¿Pero habláis en serio? preguntó Maruja asombrada¿Y por qus doce mariposas revolotearon pordas depositaron un beso octubre de 2016. nta que adjunto a esta solicitud. onal desde la desfamilé no se lo contasteis a vuestras madres?

— ¿Tás loca? Les habríamos dao una enritación que pa qué -respondió Consuelo-. Pobreticas, ya tenían bastante.

-Ya ves -continuó Dorita-. Yo a mi mae no le conté ni cuando me vino el periodo. ¡Qué vergüenza! Yo pensaba que tenía algo malo. Y muncho menos le conté que mi marío me inflaba a palos.

Maruja se quedó mirándolas un momento.

-Niñas, menos mal que estamos juntas. 
Por fin un día, sentadas alrededor de la campana, redactaron una carta al pueblo. Adela era la única que sabía escribir, porque su padre la había enseñado como al resto de sus hijos, que para eso era el maestro de Candiles. En la carta pedían el destierro de sus maridos y explicaban los abusos con pelos y señales. Empapando en tinta las puntas de sus dedos, dibujaron mariposas negras y los deditos de Mari Luz recordaron a Cordelia. Las doce mariposas revolotearon sobre el papel.

En silencio, se acercaron al balcón secreto de la cúpula que, colgado sobre el altar, levitaba frente a un ventanal que arañaba el cielo. Como una vestal, Adela alzó la carta y la dejó caer al vacío. Mari Luz comenzó a llorar $\mathrm{y}$, aunque su madre le dio teta para callarla, ya era demasiado tarde. La carta hizo piruetas sobre el altar y una sombra lo vio todo en la penumbra.

No había duda, eran ellas.

Al día siguiente el pueblo parecía un circo romano. La carta había corrido como la pólvora y los candileños esperaban ansiosos la misa de la tarde.

-Queridos hermanos -comenzó don Francisco tras leer el evangelio de la mujer adúltera-. Hoy es un día de vergüenza para este pueblo. Las jóvenes que abandonaron a sus maridos se han atrevido a escribir una carta pidiendo su destierro. ¡Qué desfachatez!

El cura lanzó una mirada diabólica a toda su grey.

- Habéis de saber que la Iglesia condena su actitud - continuó con una solemnidad nunca vista- y se avergüenza de quienes han rechazado el modelo de La Virgen, nuestra madre misericordiosa. El matrimonio es un sacramento sagrado y las esposas han de obedecer a sus maridos mientras ellos sustentan el hogar con su trabajo. He hablado con el Santo Oficio y, si estas mujeres no regresan en una semana y piden perdón, el castigo será brutal. Si alguien de los aquí presentes tiene conocimiento de su paradero, debe decírselo a las autoridades de inmediato o, de lo contrario, estará pecando como ellas.

Sagrario sintió que el sermón iba dirigido a ella, agachó la cabeza y recordó el día que el alguacil la interrogó. Todo el pueblo sabía el vínculo que tenía con las jóvenes e intentaron usarla de cebo, pero se dieron cuenta de que no sabía nada y la dejaron en paz. Aquel día se sintió traicionada. ¿Por qué no habían contado con ella? Sí, es cierto que les habría prohibido dejar a sus maridos, pero quizás las habría escuchado $\mathrm{y}$, quién sabe, hasta habría escapado con ellas. ¡Pero la dejaron sola! El llanto de la niña se le clavó como un cuchillo, como si se la hubieran arrebatado de las entrañas, y recordó la carta cayendo desde arriba. Iba a denunciarlas, como dijo el padre Francisco.

Sin embargo, primero tenía que descubrir el pasadizo secreto. Como custodiaba la llave de la iglesia, esa noche se escondió en la sacristía y no pegó ojo, pues el deseo de pillarlas pesaba más que sus párpados cansados. A altas horas de la madrugada le pareció oír ruidos cada vez más cercanos y se metió en un armario de rejilla hasta que vio temblar el cuadro y una luz salió del Purgatorio. Puri y Angustias regresaron del más allá rodeadas de un resplandor de ultratumba y cogieron un cirio de la cómoda antes de regresar a su escondite. Sagrario sonrió con malicia.

Se acabaron los bailes en otros reinos.

La mañana siguiente se fue en busca del alguacil, que vio sed de venganza en sus ojos y empezó a frotarse las manos. $\mathrm{Si}$ daba con las fugitivas levantarían una estatua en su nombre.

- Siéntese, Sagrario. Salgo un momento al baño y le tomo declaración en un santiamén.

La anciana se sentó en una silla coja y estuvo a punto de caerse, pero se agarró al escritorio y recuperó el aliento al ver un cuadro de la Virgen del Perpe- 
tuo Socorro. Sus ojos diminutos destilaban tristeza y notó que se le clavaban en el pecho como las manitas de su hijo. Un portazo anunció el regreso del alguacil.

-Mu bien, señora, ya podemos empezar. ¿Qué sabe usted de esas desgraciás?

Pero Sagrario se levantó como quien ve al diablo y salió disparada de la oficina dejando al alguacil con la palabra en la boca. No paró de correr hasta que se metió en la iglesia y, entre jadeos, se sentó en primera fila. Tardó un buen rato en recobrar el aliento y, arrodillada, empezó a rezar con voz quebrada intentando contener las lágrimas. Primero hubo silencio, pero al rato sus plegarias recibieron respuesta $\mathrm{y}$, poco a poco, se le unió un coro celestial. La anciana alzó la mirada y, una tras otra, las jóvenes se asomaron al balcón batiendo sus manos como mariposas. Sagrario recibió el saludo emocionada y elevó sus manos, que comenzaron a volar.

\section{IV}

Pasó una semana y las mujeres no aparecieron. Puesto que eran fugitivas, y a la luz del imperdonable sacrilegio, el tribunal decretó quemarlas en efigie como en los viejos tiempos. Los peces gordos del Santo Oficio llegaron desde la ciudad con hábitos blancos, capas negras y rosarios colgados en el cinto. Formando un círculo en la plaza, las once muñecas portaban sambenitos $\mathrm{y}$ corozas decoradas con llamas y diablos. Esa noche las antorchas ardieron en un acto de magia negra y las coronillas de las autoridades brillaron con el fuego de la vergüenza. La gente miró hipnotizada las estatuas, que bailaron al son de las llamas. Los niños lanzaron piedras y las mujeres las llamaron brujas entre susurros.

- ¡El Santo Oficio condena a estas mujeres del diablo a la pena de muerte y les aplica la excomunión mayor y la confiscación de sus bienes y las obliga a permanecer con sus maridos ahora y en la vida eterna!

—AAmén! — gritó el pueblo en perfecta sincronía.

El fraile entregó al alguacil las mujeres de trapo y el verdugo prendió las piras de leña, que quemaron la noche.

El pueblo profirió insultos a las llamas del pecado, tal vez porque comulgaba con las autoridades o para guardar las apariencias. Poco a poco, el fuego fue menguando y los candileños abandonaron la plaza hasta que no quedó ni un alma.
Sagrario se encerró en la iglesia y esperó un par de horas hasta que el pueblo se hubiera dormido. Abrió entonces las puertas del Purgatorio y llamó a sus amigas, que salieron del cuadro entre risas y bailoteos y se dirigieron a la plaza apilando las muñecas quemadas, que lanzaron a una carretilla. La anciana pidió que la esperaran $\mathrm{y}$, al rato, apareció con un caldero de sangre y una muñeca pequeña que lanzó junto a las otras. Entre cánticos, emprendieron la marcha al cementerio, donde buscaron los fosos vacíos y enterraron a las muñecas. Una tras otra sumergieron las manos en el caldero y marcaron sus tumbas con mariposas ensangrentadas. Mientras ardía en llamas la muñeca de Sagrario, las siluetas de unas brujas danzaron entre las tumbas.

Algunos hombres dicen que las pillaron y las quemaron de verdad, pero a nosotras nos contaron que se hicieron mariposas y volaron bajo la luna.

En Candiles se habla de leyenda y hay que contarla en voz baja y nunca, nunca, delante de los hombres, porque les hierve la sangre y pegan puñetazos en la mesa.

— ¡Eso son patrañas! —dicen.

Nosotras sabemos que no. 


\section{Referencias}

Acosta Sánchez, J. (1979). Historia y cultura del pueblo andaluz. Algunos elementos metodológicos y politicos. Barcelona: Anagrama.

Agúndez García, J.L. (2017). La narrativa popular en Andalucía. Boletín de Literatura Oral, 1, 637-671.

Althusser, L. (1971). Lenin and Philosophy and Other Essays (B. Brewster, trad.). Nueva York: Monthly Review Press.

Amorós, C. (1990). Violencia contra las mujeres y pactos patriarcales. En: V. Maquieira D’Angelo y C. Sánchez, Violencia y sociedad patriarcal (pp. 1-15). Madrid: Pablo Iglesias.

Andaluces diario (2016). El nacionalismo andaluz de Blas Infante en realidad era un antinacionalismo. El Plural. Recuperado el 15 de octubre de 2017, de: http://elplural.com/2016/03/06/el-nacionalismo-andaluz-de-blas-infante-en-realidad-era-un-antinacionalismo

Ávila Rodríguez, A. (2014). De la germinación de lo siniestro: La belleza en espejo roto. La Palabra, (24), 99-106. Doi: https://doi.org/10.19053/01218530.2505.

Centro de Estudios Andaluces (2015). El Centro de Estudios Andaluces y la Fundación Blas Infante publican la primera edición crítica de Ideal Andaluz. Centro de Estudios Andaluces. Actividades: 130 Aniversario Blas Infante. Recuperado el 15 de octubre de 2017, de: http://centrodeestudiosandaluces.es.

Cernuda, L. (1975). Prosa completa. Barcelona: Barral.

Chicharro, A. (1983). Cuestiones preliminares a la elaboración de un concepto de novela andaluza. Aexerquía: Revista de estudios cordobeses, 9, 39-52.

De la Peña Gómez, M.P. (1994-5). Aproximación entre pintura y narrativa en el costumbrismo andaluz del siglo XIX. Norba: Revista de Arte, 14-15, 229-246.

De Urioste Azcona, C. (1997). Narrativa andaluza (1900-1936): Erotismo, feminismo y regionalismo. Sevilla: Universidad de Sevilla.

Díez Sierra, M.C. (2008). Análisis de la Ley Integral contra la Violencia de Género desde la Secretaría Provincial de Igualdad. En: V. Maya Frades, Mujeres rurales. Estudios multidisciplinares de género (pp. 187-194). Salamanca: Universidad de Salamanca.

Espigado Tocino, G. (2012). Los caminos de la emancipación feminista en el siglo XIX: Andalucía y España. En: M.D. Ramos Palomo, Andaluzas en la historia: Reflexiones sobre política, trabajo y acción colectiva (pp. 25-56). Sevilla: Fundación Pública Andaluza Centro de Estudios Andaluces. 
Filardo Llamas, L. C. (2008). Joven, bella e indefensa: la transmisión de los estereotipos de género a través de los cuentos infantiles. En: V. Maya Frades, Mujeres rurales. Estudios multidisciplinares de género (pp. 267-282). Salamanca: Universidad de Salamanca.

Foucault, M. (1990). The History of Sexuality (R. Hurley. trad.). Nueva York: Vintage.

Galán Fernández, N.C. (2016). Notas para definir la literatura andaluza: del mito decimonónico a los narraluces. En: Letras del XIX Encuentro de investigadores de la lengua española. Centro Virtual Cervantes. Recuperado el 6 de octubre de 2017, de https://cvc.cervantes.es/literatura/letras_xix/ articulo4.htm.

García Lastra, M. (2008). Mujeres rurales españolas. La reivindicación de la identidad en un medio adverso. En: V. Maya Frades, Mujeres rurales. Estudios multidisciplinares de género (pp. 35-48). Salamanca: Universidad de Salamanca.

Gramsci, A. (1971). Selections from the Prison Notebooks (Q. Hoare y G. N. Smith, eds.). Londres: Lawrence and Wishart.

Guarinos, V. (1999). Algunas andaluzas oscuras. En: V. Guarinos, Alicia en Andalucía: La mujer andaluza como personaje cinematográfico. La mujer andaluza tras la cámara (pp. 113-127). Sevilla: Consejería de Cultura.

Guerra, A. (1908). El regionalismo literario en España. La España moderna, 238, 5-24.

Guichot y Sierra, A. (1999 [1922]). Noticia histórica del folklore. Sevilla: Consejería de Educación y Ciencia.

Haimovich, P. (1990). El concepto de los malos tratos. Ideología y representaciones sociales. En: V. Maquieira D’Angelo y C. Sánchez, Violencia y sociedad patriarcal (pp. 81-104). Madrid: Pablo Iglesias.

Hall, S. (1996). Gramsci’s Relevance for the Study of Race and Ethnicity. En: D. En Morley y K.H. Chen, Stuart Hall, Critical Dialogues in Cultural Studies (pp. 411-440). Londres y Nueva York: Routledge.

Haraway, D. (1988). Situated Knowledges: The Science Question in Feminism and the Privilege of Partial Perspective. Feminist Studies, 14(3), 575-599.

Infante Pérez, B. (1915). Antología de textos. Sevilla: Joaquín L. Arévalo.

Infante Pérez, B. (1982). El ideal Andaluz. Sevilla: Conserjería de la Junta de Andalucía.

Kermode, F. (1970 [1966]). The Sense of an Ending. Oxford: Oxford University Press. 
Kristeva, J. (1982). Powers of Horror: An Essay on Abjection (León S. Roudiez, trad.). Nueva York: Columbia University Press.

Ladrón de Guevara, J.G. (1977). La problemática cultural andaluza. En: M. Lombao y M.A. Sacaluga, Andalucía (pp. 91-93). Barcelona: La Gaya Ciencia.

Loomba. A. (1998). Colonialism/Postcolonialism. Londres y Nueva York: Routledge.

Lorenzo-Feliciano, V. (2016). Divas en la brega: apuntes para el estudio de Las divas de mi barrio de Carmen Montañez. La Palabra, (28), 17-26. Doi: https://doi.org/10.19053/01218530.4785.

Maglia, G. (2017). Paisaje, identidad y nación en el Caribe poscolonial: Edouard Glissant y Derek Walcott. La Palabra, (31), 89-99. Doi: https://doi.org/10.19053/01218530.n31.2017.7283.

Maquierira D’Angelo, V. y Sánchez, C. (eds.) (1990). Violencia y sociedad patriarcal. Madrid: Pablo Iglesias.

Martín López, E. (transcr.) (2010). Expediente de malos tratos de María del Carmen Alcalde, vecina de Cabra de Córdoba, contra su marido, Manuel María Gil de Arana. En: Papeles de Mujeres DM 2010. Documento del mes de julio (pp. 1-14). Granada: Archivo de la Real Chancillería de Granada.

Masanet, L. (1998). La autobiografía femenina española contemporánea. Madrid: Fundamentos.

Maya Frades, V. (2008). Señas de identidad de la mujer rural. En: V. Maya Frades, Mujeres rurales. Estudios multidisciplinares de género (pp. 17-33). Salamanca: Universidad de Salamanca.

Megías Aznar, J. (1985). Una lectura de la trilogía rural de Federico García Lorca (1). Aldaba, 4, 7-34.

Miller, H.J. (1994). Derrida’s Topographies. South Atlantic Review, 59(1), 1-25.

Montenegro de la Hoz, N.(2014). Changó, el gran putas: formas deresistencia eidentidad esclavizada enlos estudios poscoloniales. La Palabra, (24), 59-66. Doi: https://doi.org/10.19053/01218530.2501.

Moreno Navarro, I. (1981). La nueva búsqueda de la identidad (1910-1936). En: Historia de Andalucía vol. 8. La Andalucía contemporánea (1868-1981) (pp. 253-273). Barcelona: Cupsa.

Narváez, J. (1986). El testimonio. 1972-1982. Transformaciones en el sistema literario. En: R. Jara y H. Vidal, Testimonio y literatura (pp. 235-279). Minneapolis: Institute for the Study of Ideologies and Literature.

Ortega, J. (1981). Conciencia social en los tres dramas rurales de García Lorca. Granada: Universidad de Granada. 
Páez Sandoval, C. (2017). El erotismo como política de lo íntimo en el cuento "Valle Alto" de Yolanda Oreamuno. La Palabra, (31), 161-175. Doi: https://doi.org/10.19053/01218530.n31.2017.7277.

Pérez Grande, M.D. (2008). Grupos de apoyo y autoayuda de mujeres supervivientes de violencia de género. En: V. Maya Frades, Mujeres rurales. Estudios multidisciplinares de género (pp. 339362). Salamanca: Universidad de Salamanca.

Ramos Palomo, M.D. (2012). Andaluzas en la historia: Reflexiones sobre política, trabajo y acción colectiva. Sevilla: Fundación Pública Andaluza Centro de Estudios Andaluces.

Raymond, J.G. (1986). A Passion for Friends: Towards a Philosophy of Female Affection. Boston: Beacon.

Redondo Goicoechea, A. (2001). Introducción literaria. Teoría y crítica feministas. En: C. Segura Graíño, Feminismo y misoginia en la literatura española. Fuentes literarias para la Historia de las Mujeres (pp. 19-46). Madrid: Narcea.

Rodríguez Salas, G. (2017). Hijas de un sueño. Granada: Esdrújula.

Ruíz Copete, J.D. (1977). Andalucía: carácter y sentido de una tradición literaria. Sevilla: Real Academia Sevillana de Buenas Letras.

Ruíz Muñoz, M.J. (2008). Argumentos, personajes y escenarios para la elaboración de la imagen de Andalucía en el cine. Palabra clave, 11(1), 123-139.

Salvador, A. (1980). Andalucía, ¿una cultura nacional? Argumentos, 35-36, 56-59.

Segura Graíño, C. (2001). Introducción histórica. Las fuentes literarias en la Historia de las Mujeres. En: C. Segura Graíño, Feminismo y misoginia en la literatura española. Fuentes literarias para la Historia de las Mujeres (pp. 13-18). Madrid: Narcea.

Sierra Díaz, D.C. (2016). El Muntu: la diáspora del pensamiento filosófico africano en Changó, el gran putas de Manuel Zapata Olivella. La Palabra, (29), 33-44. Doi: https://doi.org/10.19053/01218530. n29.2016.5699.

Smith, B.G. (1998). The Gender of History: Men, Women and Historical Practice. Cambridge: Massachussetts: Harvard University Press.

Trenzado Romero, M. (2000). La construcción de la identidad andaluza y la cultura de masas: el caso del cine andaluz. Revista de Estudios Regionales, (58), 185-207.

Vanegas Vásquez, O. K. (2014). Héroes vagabundos: Memoria narrativa de la guerra colombiana. $L a$ Palabra, (25), 43-56. Doi: https://doi.org/10.19053/01218530.2868. 
Vargas Quiroz, A. P. (2014). Me gustan tus ojos miopes (o del diálogo con Hélène Cixous para llevar al cuerpo, a la literatura, a la vida). La Palabra, (25), 143-156. Doi: https://doi. org/10.19053/01218530.2877.

Von Franz, M.L. (1982 [1970]). An Introduction to the Interpretation of Fairytales. Dallas, Texas: Spring Publications. 
